\title{
MATIJA MAJAR ZILJSKI \\ ENLIGHTENER, POLITICIAN, SCHOLAR
}

\section{ISKRA VASILJEVNA ČURKINA}

Matija Majar Ziljski left a significant mark in different spheres of cultural, educational and political life. During the revolution of 1848-1849, he was an Slovenian ideologist and the first to publish his political program entitled United Slovenia. After the revolution, he gradually turned away from Pan-Slovenian affairs, the main reason for this being his idea about creation of Pan-Slavic literary language. His position on this matter strengthened after his trip to the Ethnographic Exhibition in Moscow in 1867 and his friendship with Russian Slavophiles.

Keywords: Matija Majar Ziljski, biography, Panslavism, Ethnographic exhibition, Moscow.
Matija Majar je bistveno zaznamoval različna področja kulturnega, vzgojnega in političnega življenja. Med revolucijo 1848-1849 je bil eden vodilnih slovenskih mislecev in prvi, ki je objavil politični program Zedinjena Slovenija. Po revoluciji se je postopoma preusmeril od vseslovenskih vprašanj v ustvarjanje panslovanskega/vseslovanskega jezika. Ta usmeritev se je še bolj okrepila po njegovem potovanju na Etnografsko razstavo $v$ Moskvo leta 1867 in zaradi prijateljstev z ruskimi slavofili.

Ključne besede: Matija Majar Ziljski, biografija, panslavizem, etnografska razstava, Moskva.

Matija Majar Ziljski was one of the most outstanding Slovenian national activists of the $19^{\text {th }}$ century. He was born on 7 February 1809 in a small village of WittenigVitenče in the Gail-Zilja river valley. His father, a poor rural tailor, was a literate man. He taught the boy to read in German and Slovenian. With the financial support of Canon Biseling, Matija graduated from high school in Klagenfurt-Celovec and later from high school in Graz-Gradec. From 1833 to 1836, Majar studied at the seminary in Klagenfurt-Celovec, where he was greatly influenced by the chaplain Anton Martin Slomšek, a future Bishop of Lavant. In 1837, Majar was ordained a priest; he was assigned to be a priest in a parish, and then an expeditor in the bishop's office. It was there that he met the outstanding Slovenian educator and priest Urban Jarnik, whom Majar regarded as his teacher.

In the prerevolutionary years, Majar's activities were only educational. He paid a great deal of attention to schooling as a means to educate peasants, whom he regarded as the foundation of both Slovenian patriotism and appropriate farming practices. In this regard, he was influenced strongly by Simon Rudmaš, an outstanding Slovenian educator in the Carinthia region and a school advisor. Majar wrote:

The benefit provided to peasants will be useful to many people, since no other class has as many people as peasants: other classes have several thousand people and the peasant class has more than a million. ${ }^{1}$ 
Majar thought that peasants should be enlightened through education about efficient farm management, and that schools should be responsible to educate peasants. "Education should be the first and the last concern of a Slovenian patriot right after the thought of God." Formal education had to be in the Slovenian language, and should be provided by priests, teachers and school authorities. (Novice, 2 November 1845) In the 1840s, Majar wrote a textbook to help teachers who were educating children in Slovenian. Priests were also obliged to learn the Slovenian language. For this purpose, a Slovenian religious magazine needed to be established, which would contain articles about school, church offices, history of the church, and sermons in Slovenian.

Majar called for establishment of national societies and the publication of Slovenian newspapers and books. These would unite Slovenian patriots, who would bring Slovenian culture to the masses. Majar welcomed enthusiastically the establishment of the Slovenian newspaper Kmetijske in rokodelske novice and became one of the most active correspondents of the newspaper, especially until the year 1848.To his friend Stanko Vraz he said:

This newspaper is our first step in our land. It is essential, since no-one can move to the next stage without first taking the first one... I hope this newspaper will wake us up, us Slovenians. (Novice, 29 October 1845) Majar dedicated a considerable amount of time to collecting Slovenian folklore. In 1837, he met the Styrian educator Stanko Vraz, with whom he travelled (and later alone) across almost the entire Slovenian territory. They recorded folk songs, fairy tales and proverbs. Vraz became Majar's most trusted correspondent up to his death in 1849. Majar visited Slovenians in Carinthia, Styria, Carniola, Gorica (Gorizia), and Venetian Slovenija (Benečija - Veneto). He published some of the collected songs in the Slovenian and Croatian press, and published book entitled Pesmarica cerkvena in 1846. Majar's trips throughout Slovenian lands led him to the conclusion that the Slovenians in Carinthia, Styria, Gorica (Gorizia) and Venetian Slovenija were a single nation. He shared his remarks with Vraz. "I visited the Slovenians in Gorica and Benečija," Majar said to his friend in 1842. "Slovenians - that is what our brothers call themselves in Benecija and Gorica and all the way to Trst (Trieste), not 'sklavonts' as they are named by foreigners there." Majar pointed out with pleasure that women's clothes in Kras (Karst) looked like clothes in Styria, Carniola, Gorica; and that dances that he saw in Brda of Gorica were just the same as in Styria, Carinthia and Carniola. ${ }^{3}$ Thus before the revolution in 1848, Majar came to the idea that people living in Carniola, Carinthia, Styria, Gorica, and Venetian Slovenia were a single nation - the Slovenians. However, Majar thought that Slovenians represented too small a reading audience to develop their own literature successfully. For this reason, he supported the Illyrian Movement that had started in Croatia. The Illyrian Movement was based on the theory forwarded by Czech and Slovak enlight-

2 Trezor, Nacionalna i sveučilišna biblioteka (National and University Library), Zagreb, Majar - Vraz, 31 July 1843.

3 Trezor, Majar - Vraz, 1842. 
ener Jan Kollar about the existence of four main dialects of the Slavic language (Russian, Polish, Illyrian and Czechoslovakian), and its leader Ljudevit Gaj claimed it was necessary to create a unified literary language and culture for all South Slavs (Illyrians). This idea echoed in the hearts of some Slovenian national activists, especially in Styria and Carinthia, where Germanization endangered the local Slovenian population more than in other regions. Stanko Vraz and Matija Majar became among the most devoted followers of Illyrism. Vraz as well as Gaj thought that the basis of the literary Illyrian language should have been the Shtokavian dialect of the Serbo-Croatian language. As for Majar, he believed that it should have been the dialect of the people living between Ljubljana and Rijeka (i.e. the intermediate dialect between the Kajkavian dialect of the Serbo-Croatian language and Slovenian). According to Majar, Illyrism is the only solution for Slovenians.

Everything is useless, he wrote to Vraz, ... until Illyrian subdialects unite into one unified literary dialect common to all of us. Without such integration, Slovenian literature is a bird without feathers. We are only able to publish prayers and religious books in the Slovenian subdialect... Having nothing else, we are unable to proudly join the educated European nations. (Novice, 17 January 1844)

In 1848, Majar published the book entitled Rules How to Form Illyrian Dialect and Pan-Slavic Language as a training aid for the formation of the Illyrian language. The very name of this tractate indicates that at the time Majar did not intend to stop creating the Illyrian language and was planning to create a united literary language for all Slavs in the future.

Majar thought that the first step towards the formation of a unified literary Illyrian language was the creation of a unified alphabet for South Slavs. In early 1840s, Croatians used Gaj's alphabet, which is a variation of the Latin alphabet taken from Czechs. At that time, Slovenians used the Bohorič and Metelko alphabets, which are variations of the Latin alphabet created by Slovenian protestant Adam Bohorič in the $16^{\text {th }}$ century and Slovenian philologist Franc Metelko, who published his grammar of the Slovenian language in 1825.

Majar promoted Gaj's alphabet for Slovenians. He found it interesting because it was spread among almost all Catholic Slavs in Austria. He emphasized: "We can read their books, and they can read ours." (Novice, 1 January 1845) Majar convinced the editor of Kmetijske in rokodelske novice Janez Bleiweis to start publishing it in Gaj's alphabet. At the end of 1847, he told Vraz about it:

First, the old spelling was used in Kmetijske novice, and then they gradually introduced a new one, which allowed everybody to use whichever spelling they liked ... Already after three years, this absurd mess turned into a noble, fervently expected agreement on spelling. ${ }^{4}$ 
More than forty years later, Majar wrote to J. Kleinmayr (the Slovenian writer who worked on his biography), saying that one of his main achievements was participation in introducing the spelling for Slovenians that was used by Czechs, Slovaks and Croatians. ${ }^{5}$

Even before the Revolution of 1848/1849, Majar had contact with a number of Slovenian and Slavic national activists. In addition to those already mentioned above, he was acquainted with the Czech Vilem Lambl, and was also in correspondence with Czech enlightener Vaclav Hanka as well as the leader of the Croatian Illyrians Ljudevit Gaj. In 1841, Majar was visited by Russian Slavist Ismail I. Sreznevsky, whom he gave part of the songs he collected.

The news about the revolution in Vienna reached Klagenfurt-Celovec on 16 March 1848. The following day Majar wrote the article entitled 'What We, Slovenians, Demand', which was published in Novice on 29 March 1848 (Kirilina 2000: 33). It became the first printed Slovenian speech for a United Slovenia.

We don't feel scorn for any nation, Majar wrote, ... Let everyone live as they like in their country, in their home... Let our deputies in Vienna demand that we could gradually introduce our Slovenian language to schools and offices in the time we want and in the way we want. (Novice, 29 March 1848)

Although Majar did not speak about unification of Slovenians directly in his article, by Slovenia he apparently meant all the regions inhabited by Slovenians, as he emphasizes the necessity of the introduction of the Slovenian language to schools and offices.

Apart from this article, Majar wrote several petitions to authorities, which he gave to Slovenian patriots to sign. For instance, Majar agitated strongly among seminarians in Klagenfurt-Celovec, calling them to sign his petition. A correspondent of Gaj's newspaper Narodne novine $e^{6}$ described an interesting fact in his article. In the seminary of Klagenfurt-Celovec, 30 seminarians put their names to Majar's petition, but the chaplain of the seminary Pikle abolished these signatures (Pleterski 1965: 431). Furthermore, on 6 April M. Slomšek warned the Styrian abbot Matija Vodušek, saying that the Slavist of Celovec Matija Majar is out of his mind, writing petitions as he pleases, and collecting signatures for them. If he addresses the clergy of Lower Styria, please deny any assistance to him" (Pleterski 1965: 31).

There is a leaflet signed by Majar with the same title as his article in Novice: 'What We, Slovenians, Demand'. In this leaflet the demands of Slovenians were described in more detail in six planks.

1. Slovenians must unite and have a general local assembly.

2. The Slovenian language in Slovenian regions must have the same rights as German has in German regions and Italian in Italian regions.

5 Collection of manuscripts of the National and University Library (NUK), Majar - Kleinmayr, 1880.

6 Narodne novine experienced many name changes through theyears (http://www.nn.hr/174GodineNarodnih). 
3. Slovenians are free to introduce the Slovenian language to all institutions, universities and secondary schools whenever they choose.

4. Each civil servant must learn the Slovenian language before being appointed to a civil institution in Slovenian regions.

5. In each high school in Slovenia, Slovenian language teachers must understand all Slavic dialects.

6. Slovenians do not want to be in the German alliance, they are loyal to their emperor and constitutional government. "Any alliance with the Germans (outside Austria) would obviously hurt us, they would dominate us with the German language and culture, take over our cities, then our castles and finally our fields and vineyards, as this has already happened in some areas." (Zwitter 1964: 117)

Therefore Majar's program is more detailed in the leaflet than in the article. The dissatisfaction of authorities with Majar's activity culminated with his expulsion from Klagenfurt-Celovec. He was sent to a remote parish in the mountains of Višarje-Monte Lussari. However, even there Majar did not rest; he started to cooperate actively with newspapers Novice and Slovenija, which first appeared in Ljubljana in 1848.

Majar's political program was formed during the revolution; its main idea was a United Slovenia. No other Slovenian politician introduced such a well-knit and clear program in 1848 as he did. Majar's program was formed after the crackdown of the Slavic Congress and suppression of a rebellion in Prague, when Majar was disappointed with a possibility of an alliance with Germans. The major point of his program was the separation of Austrian Slavs from Germans and Hungarians, whom he regarded as the most realistic threat for Slavs. Majar justified the separation of Slavs by the fact that "all the Slavic tribes in our Empire are only one Slavic people". Austria should continue to exist, but within it all Slavs should form a special autonomous entity by the name of Slavia. Austria should have a common parliament and government that would be responsible for international affairs, finance, military and trade. Slavia would also have its own parliament and government handling Pan-Slavic affairs. Slavia would be a federation of Slavic tribes, each of which would have its own skupstina, government, governor and military commander. In total, Majar numbered eight Slavic tribes in Austria: Slovenians, Dalmatae-Croat-Slavonians, Serbs, Czechs, Moravians, Slovaks, Poles, and Rusyns (Slovenija, 26 December 1848).

Majar was one of the few Slovenian liberals who tried to link a national program with some economic requirements: alleviation of taxes, abolition of feudal duties paid for a ransom. Many Slovenian politicians supported Majar's program. At the end of 1848, he proudly told Vraz: "My word is valued by Slovenians" 
were not an exaggeration. Slovenian liberals of the Viennese association Slovenia (A. Globočnik, M. Šemrajc), former Illyrians, welcomed Majar's speeches in the press; even the moderate Bleiweis visited Majar in the village of Višarje and later described him in his newspaper as a tireless friend of mother Slavia.

Majar strongly opposed the German and Hungarian programs but fiercely supposed the Slav struggle for their rights. He felt pity for Czechs during the rebellion in Prague and criticized the crackdown of the Slavic Congress. Although none of the Carinthian Slovenians took part in the Congress, Matija Majar, Andrej Einspieler, and other Slovenian patriots sent greetings (Kirilina 2000: 61). In a conflict between Hungarians on one side and Serbs and Croatians on the other, Majar's sympathy was on side of the latter. In May 1848, he encouraged 14 Carinthians to send a greetings letter to the Serbian skupština. It said particularly: "Only on condition of harmony between Slovenians, Serbs and Croatians will the sun of old happiness and new glory return to us" (Novice, 29 March 1848). Majar was particularly friendly to Serbs and Croatians, which was without a doubt a result of his Illyrian beliefs.

Majar did not feel any particular sympathy to Russia at the time. In his article 'Slavs and Germans' he denied the claims of German politicians that Slavs dreamed to fall under the power of Russia. Majar emphasized that "Freedom is dearer to us than any violence, whether it comes from Russia or Frankfurt" (Slovenija, 18 June 1848). In his article 'Harmony of Slovenian Societies' published in December 1848, Majar repeated the words of the ideologist of Czech politicians F. Palacky: "We, Slavs, say that if there was no Austrian Empire, we would re-create it" (Slovenija, 12 December 1848). In 1848, Majar firmly supported Austrian Slavism.

Evaluating Majar's role in 1848, one can agree entirely with the opinion of the Slovenian historian Janko Pleterski that Majar's activity during the revolution played a big role in the further development of the Slovenian national movement. First, he was the first to publish a Slovenian political program, United Slovenia, which became the general program of Slovenians for many decades. Secondly, Majar was the first to promote it among peasants (Pleterski 1965: 30-31). Church authorities avenged Majar for his activity during the revolution: from the end of 1849 to 1851 he changed four parishes, which were populated mainly by Germans. Only in 1851 was he assigned to the Gorje parish, where he stayed for 19 years.

Majar was deeply concerned about the reaction movement. He felt it forthcoming before the declaration of the Octroyed Constitution (7 March 1849). "They want to sell us to Frankfurt again," he wrote to Vraz on 4 March 1849.

Scribes and pharisees resist the Slovenian language in all possible ways; nobles and civil servants act as in the time of Metternich. Bishops have sent a petition to the ministry that their loyal lambs shouldn't be relieved of duties and gravel work... We, Slovenians, used to be united in one kingdom (the Illyrian kingdom nominally existed up to 1849)... 


\section{before, they only wanted to include the Slovenians of Styria... and now we will be divided into even less parts than before. ${ }^{8}$}

Majar felt great sorrow at the suppression of a number of newspapers, especially the liberal Slovenija. On 2 June 1852, he wrote to Josip Muršec, who became his close correspondent after the death of Vraz in 1849: "A nation without a political newspaper is like a man without a tongue; it can't speak and protect its rights; it becomes a vassal of other nations." Majar thought that a new newspaper should be addressed to all Yugoslavs. With such a newspaper, Slovenians could feel more confident than with the purely Slovenian Slovenija. Majar asked Muršec to introduce the idea of Yugoslav political newspaper's publication to Styrian patriots Terstenjak and Macun. However, six months later, on 5 December 1851, Majar saw that it was impossible to organize this political newspaper and wrote to Muršec: "It is hopeless to start any policy; we should only monitor what is going on and carefully support literary activities. This is our policy now" (Ilešič 1905: 47-49).

By literary activities, Majar meant the creation of Illyrian and Pan-Slavic languages. They should have been promoted by the magazine Slovenska bčela, which was first published in Klagenfurt-Celovec in 1850. In addition to Majar, Anton Janežič, a teacher, and Andrej Einspieler, a priest, supported this project. The purpose of the magazine was "to awaken Slovenians to the Slovenian spirit and love for the native language... introduce them to the literature of their Slavic brothers" (Prijatelj 1955: 219). The magazine contained historical novels with Slavic content by Janez Trdina and Josipina Turnograjska; essays about famous Slavic cultural figures: Ján Kollár, France Prešeren, Vasilij A. Zhukovsky, Nikolai V. Gogol, Adam Mickiewicz, Jernej Kopitar, Ivan Gundulić and others. Furthermore, it also contained articles about Slav customs; fragments of Pavel J. Šafarik's work History of Slavic Literature, articles about Illyrian and Pan-Slavic languages; and stories about Russian history. Some articles were published in Illyrian and Pan-Slavic languages according to Majar's methodology (the articles written by Janežič and Majar, and the section entitled "Smešnice", which was written by Majar). In 1853, the magazine was abolished because the number of subscribers was too small.

The creation of a Pan-Slavic language was also promoted at that time by Styrian enlightener and lawyer Radoslav Razlag, who published two literary miscellanies Zora in Graz-Gradec in 1852 and in Zagreb in 1853. The ideas of the older generation of Illyrians exerted considerable influence on the Slovenian school youth. Slovenian schoolboys in Klagenfurt-Celovec, Celje and Ljubljana published their manuscripts in Slavia.

In 1852, the first Slovenian publishing house entitled the Society of St. Mohor was established at the initiative of Einspieler and Janežič and with the active assistance 
of Slomšek and Majar in Klagenfurt-Celovec. It published books for peasants with moral-religious and practical-economic content. In the early 1850s, Majar was fighting for a Slovenian school in the community Straja vas (Hohenthurn), which included the village Gorje. Majar was also fighting against Zupan Milonig, a rich peasant, who in 1848 stood for a Slovenian school but in the early 1850 s changed his views. The only result Majar managed to achieve was that the Law of God (Zakon Božji) in schools was taught in Slovenian. Majar still dedicated a great deal of time to collecting folk songs, and in relation to this project began correspondence with the Czech writer Božena Nemcova.

The political situation in Austria improved significantly due to the adoption of the October Diploma (1860) and the February Patent (1861), which gave Austrian people certain rights, including the freedom of speech and assembly. As in 1848, Majar was once again the first to produce a political program of Slovenians. In early March 1861, he published the article 'Our Situation' in Novice. As at the beginning of the revolution in 1848, in this article Majar called for the introduction of the Slovenian language in schools and civil institutions as well as for the consolidation of all Slovenian regions in one province with a general local assembly. Moreover, Majar stated that it was necessary for Slovenians to enter into a fraternal alliance with Croatians as well as to maintain open relations with other Slavs, especially Austrian Slavs (Novice, 13 March 1861; Novice, 20 March 1861).

However, Majar gradually left Pan-Slovenian affairs in the middle of the 1860 s. There were several reasons for this. The first one was the appearance of a new generation of Slovenian politicians, who in the 1860s introduced a political program of Inner Austria, that involved a revival of the old administrative entity that existed from 1564 to 1747 and united the provinces of Carniola, Carinthia and Styria. The Slovenians would amount to $43 \%$ of the population. The second reason was that Majar switched his focus to developing united Slavic ideas.

In the 1860s, Majar was active above all in the region of Carinthia. He took part in the organization and functioning of Slovenian societies, preparing and carrying out various national meetings and festivals. With the help of Majar and Einspieler, a Slovenian reading hall opened in Klagenfurt-Celovec on 24 January 1864; it became a cultural and educational center for the Slovenians in Carinthia.

Majar was also interested in Pan-Slovenian affairs. He was one of the first members of the Slovenska Matica (established in 1864) and took part in its first committee. Majar regarded it as a society that united Slovenian scholars and helped them publish their papers, such as reviews of literary works of other Slavic tribes, articles about Slovenian and Slavic history etc. These would all be published biweekly as a special academic supplement to Novice. He shared these plans with Muršec in his letter in January 1865 (Ilešič 1905: 47-49). The development of Matica took a different course though, so it became of no interest to Majar. 
In 1863, Majar published a book about Cyril and Methodius on the occasion of the $1000^{\text {th }}$ anniversary of their arrival to Moravia. However, he paid most of the attention to the creation of a Pan-Slavic language. Most activists that supported this idea in the first half of the 1850s stopped believing in the possibility of its creation. But Majar was convinced that this was necessary, and worked hard until his death to make his dream come true. In 1865, he published Vzajemna slovnica ali mluvnica slavjanska (Reciprocal Slavic Grammar) in Prague. In 1880, Majar noted in a letter to Julij Kleinmayr (the teacher at a high school in Klagenfurt who wanted to write Majar's biography and collected material for it): "This is my most important literary work."

After the declaration of the Octroyed Constitution, Russophile sympathy among the Slavs in Austria began to grow. It increased substantially in the 1860s, when in Austrian political circles heated debates about the future development of Austria were taking place. One of the political groups (court nobility and German liberals) stood for the strengthening of centralism; the other (the Hungarian ruling elite and part of the Viennese court camarilla) urged for the establishment of a dual state in which the Hungarian and German sectors would be entirely autonomous and would have a common emperor and several common ministries. In this case, some Slovenians would fall under the power of Germans, and the remaining Slovenians under the power of Hungarians - without having equal rights. The third political group aimed to rebuild Austria on a federative basis according to the old traditional provinces and consisted of two factions: the conservative nobility who resisted liberalism in their provinces, and Slavic politicians who feared a strengthening Germanization and Hungarization in case the other two groups won. By the mid 1860s, the threat of dualism became very realistic. It led to a further growth of Russophile sympathy among Slavs. Such public opinion was especially strong during the Ethnographic Exhibition and the Slavic Congress in Moscow in 1867.

In 1865, the Ethnographic Exhibition Committee decided to establish a Slavic department in Moscow. Mikhail Fedorovich Raevsky, chief agent of the Moscow Slavic charitable committee in Austria and archpriest of the Orthodox Church at the Russian embassy to Vienna, was authorized to ask Slavic national activists to send (for free or at a charge) ethnographic artifacts applying to their nations. Raevsky got in touch with the most powerful people among the Slavs. Many of them answered this call and started to collect and send the required materials to Raevsky. The most valuable present was sent to him by Matija Majar. In March 1867, Einspieler's newspaper Slovenec wrote: "Matija Majar has bought the Zilja's costumes and sent them to the Slavic Exhibition in Moscow. There are costumes of the bride, the fiancé, the bridesmaid, the matchmaker etc., and bride's dowry - a chest, bedclothes, and a spinning wheel" (Slovenec, Celovec, 19 March 1867).

9 Collection of manuscripts at the National and University Library (NUK), No. 30/49, Majar Kleinmayr, 1880. 
Majar was invited to the Ethnographic Exhibition among several scores of Slavic activists from the Habsburg Monarchy and the Balkans. Altogether only 10 Slovenians received such invitations. The Austrian authorities tried to cancel this trip in various ways; the centralist and dualistic press attacked the invited activists. All Slovenian politicians who received the invitation refused to go to the exhibition, with various excuses. Only Majar and two less influential Slovenian activists, the merchant Ivan Vilhar and the lawyer Alexandr Hudec, went to the exhibition. Delegations of other Slavs from the Habsburg Monarchy were more influential, in particular the Czechs, who were presented by their leaders František Palacky and František Rieger.

Starting from early May 1867, Majar spent a month in Russia among other guests, mainly in Moscow and St. Petersburg. The exhibits he presented were a big sensation; the Russian press regarded them to be the best in the Slavic department. They were highly appreciated by Kharkiv University professor Petr A. Lavrovsky and Moscow University professor Nil A. Popov. Emperor Alexander II, who visited the exhibition, especially noted the exposition based on the materials presented by Majar (Curkina 1978: 171-174).

In Moscow, Majar made friends with important members of the Moscow Slavic charitable committee; he established particularly close ties with professors of Moscow University Mikhail P. Pogodin and Nil A. Popov. He took part in almost all official events and many informal meetings of Slavic leaders. At the meeting at the apartment of Pogodin on 26 May 1867 were present the Czechs Palacky and Rieger, the Serbs Jovan Subotić and Milan A. Petronijević, the Slovak Pavel J. Šafarik, the Croatian Ljudevit Gaj and others. They discussed many problems concerning the cultural cooperation of Slavs, including the establishment of a Pan-Slavic magazine.

After the trip to Russia, Majar's name became very influential and respected among Russian Slavists and Slavophiles. The exhibits presented by Majar won the Second prize at the exhibition (only the crowned heads and Raevsky could get the First prize). The Russian philological Society and the Natural Science Society at the Moscow University appointed him a full-time member; and he became a correspondent at the Novorossisk University in the early 1870s.

For Majar, the trip to the Ethnographic Exhibition showed the bright side of the idea of Slavic unity. Meetings, banquets, discussions about Slavic affairs with likeminded men, and their friendly support gave Majar a boost in his further activities towards strengthening of relations between Slavs, especially the creation of a Pan-Slavic language. After Majar's return to Gorje, he had troubles with the authorities but he managed to prove that the purpose of his trip to Moscow had been purely informative, not political. As a result, his punishment was reduced to a small fine.

Russophile opinions of Majar rose significantly. In 1867, he published Russian Grammar for Slovenians (Slovnica ruska za Slovence) in Vienna, issued at expense of Blaž, a Slovenian merchant in Rijeka. In spite of its disadvantages, this grammar be- 
came the only educational tool for Slovenians who wanted to learn Russian until the publication of Russian-Slovenian Dictionary with Russian grammar by M. M. Hostnik in 1897.

In 1870, Majar voluntarily left his parish in Gorje and became a beneficiary at the Križna gora-Kreuzbergl near Klagenfurt-Celovec with a pension of 210 guilders per year, which was only half of the average pension of a parish priest. At the same time, Majar was again in the center of cultural life of Carinthian Slovenians.

In the late 1860 s, there was a rise in the Slavic national movement against dualism in the Habsburg Monarchy. It also involved the Slovenian regions; Slovenian politicians abandoned the program of Internal Austria and declared again that their purpose was to establish a United Slovenia. Liberals carried on with agitation among grassroots to support this program. From August 1868 onwards, they began to organize mass outdoor rallies - tabori, where they discussed relevant problems of the Slovenian national movement. In August 1871, 18 meetings were held, and each of them had between 5000 and 6000 participants. The biggest one gathered 30.000 in Vižmarje near Ljubljana. At the tabori, they discussed demands about the United Slovenia program, consolidation with other South Slavs, and solidarity with other Slavs. Slovenian conservatives (Old-Slovenians) also joined the tabori movement.

The tabori movement also reached the Carinthian Slovenians. They were led by the Trdnjava society that was established in December 1869 by liberals. They organized three rallies in Bistrica near Pliberk (31 July 1870), in Žoprače-Selpritsch (18 September 1870), and in Zgornje Buhlje-Oberwuchel not far from Klagenfurt-Celovec (6 August 1871). Majar was an active participant in the meeting in Žoprače. He described this to N. A. Popov,

On 18 September we, the almost dead Carinthian Slovenians, had a splendid tabor that gathered ten thousand people. We gave six speeches. I was entrusted with the first speech about United Slovenia, and I happily agreed ... When I finished, [everybody] exclaimed three times, "Glory to Slovenia!"”

Although after his return to Moscow, Majar took an active part in the work of Trdnjava and tabori, cooperating with liberals, his efforts were mainly directed at creation and expansion of a Pan-Slavic language.

Before leaving Gorje in June 1870, Majar wrote a letter to N. A. Popov (a duplicate letter was sent to Pogodin) and asked him for a position in Russia, where he would be able to teach students comparative Slavic grammar or edit a Pan-Slavic magazine. ${ }^{11}$

Majar was highly respected by Slavophiles, and they tried to find a position in Russia for him. They thought that the Novorossisk University in Odessa would be

10 Manuscript department of Russian State Library (MD RSL), fund 23, copy 13, file 19.

11 MD RSL, fund 25, copy 13, file 19. 
the most appropriate for him. S. P. Golubtsov, the curator of an educational circuit in Odessa, addressed the University's professor Viktor I. Grigorovich with a request about Majar. He answered that due to his age and evolving eye disease it would be difficult for Majar to teach, therefore it would be better to give him a position of a Catholic priest in some Catholic settlement in southern Russia. ${ }^{12}$ The Minister of Education, D. A. Tolstoy, was ready to pay the costs of Majar's emigration. However, Majar refused to immigrate to Russia under such conditions.

In a letter to Popov dated 13/25 January 1871, Majar thanked him for his care and added: "I would be more successful in promoting interests of Slavic unity as an editor of a united magazine in Vienna." He developed his plan for the magazine that would be organized into three sections.

There would be Russian articles in the first section; the second one would contain articles printed in the Cyrillic alphabet in an Inter-Slavic language that would be as close to Russian as possible; the third section would be composed of articles in our different literary languages, printed first in the Cyrillic and Latin alphabets. Eventually together they would be close to the Russian language also in grammatical forms. ${ }^{13}$

However, Majar did not manage to fulfill his promise of publishing the magazine mainly in Cyrillic. Slavjan (The Slav), which was published since the beginning of 1873 in Klagenfurt-Celovec, was almost completely printed in the Latin alphabet except for Majar's work About the Traces of the Proto-Slavs and several articles from the Russian press.

In his letters to Popov and Pogodin, Majar explained that his magazine would be an entirely literary one and that it would not deal with political and religious problems. He did not want to deal with these questions both because he wanted to avoid problems with censorship, and because he wished his magazine to be non-partisan in the Slovenian regions, "not intervening in quarrels, disputes, lawsuits and subtle things of separate tribes".

The creation of a Pan-Slavic language and unification of Slavic intelligentsia around the magazine were only means to the greater end. Majar formulated this purpose in his letter to Pogodin in 1875:

"We are close to the danger that Slavic dialects would separate and grow apart, so that not only dialects but also particular Slavic languages with particular literatures and folks would appear... In such a way, the 80-million nation would come apart, which would be a grievous loss and harm for all Slavs, Russian and non-Russian. The Slavjan works hard so that Slavic tribes won't grow apart anymore, but instead drift together." 14

12 MD RSL, fund 86, copy 3, file 14.

13 MD RSL, fund 23, copy 13, file 19.

14 The State Archive of the Russian Federation, fund 1750, list 1, file 55. 
In Majar's opinion, saving the Slavs as a single nation was the only way to protect his dear Carinthian Slovenians from takeover by Germans. However, this purpose was in conflict with the historical process: in the last third of the $19^{\text {th }}$ century there had been no unified Slavic nation yet and its recreation was an unachievable Utopia.

The magazine Slavjan, established by Majar, existed for three years - from 1873 to 1875 . Almost all the articles were written by Majar except for some correspondence. Their main idea was the necessity of Slavic consolidation and creation of a PanSlavic language in order to prevent assimilation with the neighboring nations. In the magazine, he raised the question of a Pan-Slavic literary language adoption by Slavs differently than in his letters to Popov. Majar stated that Slavic nations should not abandon their languages and customs; however, to the outside world they should act as a single nation with a unified language and culture. At the same time, he thought that none of the existing or former Slavic languages could play the role of the PanSlavic literary language, which could only be an artificially created language. Majar rated national movements and national activists of different Slavic nations by their devotion to Slavic unity.

When establishing his magazine Slavjan, Majar hoped for financial assistance from his friends. "Help me get some subscribers," he wrote to Popov in November 1872. Popov complied with his request: in six weeks, Majar thanked him for 50 Russian subscribers. ${ }^{15}$ In fact, all the money (100 rubles) was paid from the fund of the Moscow Slavic charitable committee. Financial assistance to the magazine in the amount of 100 rubles per year continued in 1873 and 1874. Majar asked the Moscow committee to raise a subsidy and take the Slavjan magazine under its full support. In the beginning of 1875 , Majar received the next scheduled 100 rubles. The Moscow committee could not afford more subsidies because a rebellion of Christians against the Turks broke out in Bosnia-Herzegovina, and the East crisis began. In the last issue of the Slavjan, Majar, saying good-bye to its subscribers, pointed at the reason for the magazine's shutdown: "when the guns shoot, nobody reels". (Slavjan, $10,1875)$

After closing down the Slavjan, Majar retired from national activity. The reason for this was his disappointment with the insufficient possibilities of expanding a PanSlavic language among Slavs. Majar himself realized it. On 31 December 1875 / 12 January 1876, he informed N. A. Popov about the suppression of the Slavjan and about his intention to write a book entitled Traces of Proto-Slavs and Education of Proto-Slavs. In the same letter, he explained to his Russian friend the main reason for his magazine's failure.

Among Slavs, who use the Latin alphabet, the Cyrillic alphabet is poorly
employed. Our schools are entirely Non-Slavic; consequently professors,

15 MD RSL, fund 23, copy 13, file 19. 
students and all educated people of Slavic blood are poorly inspired by Slavism and unity. Slavjan was primarily aimed at them, and this is why few subscribers were among them. Until recently, only our sincere patriots had subscribed to the magazine, but because patriots are few, the amount of subscribers is small. ${ }^{16}$

Moreover, Majar's activity was affected by his growing age and health deterioration, especially his eye disease, which finally led to complete blindness. His financial situation was bad, his half pension was not enough to sustain him. Furthermore, the Church authorities, encouraged by Bishop Funder, started to harass openly him.

In the fall of 1883, Majar took the most important books from his library and moved to Prague, leaving his home forever. On 6 December, Majar wrote to Kleinmayr: "I've moved from Klagenfurt to Prague. It was impossible for me to stay in the Križna gora (Kreuzbergl)... You know this town very well. I've also received a higher pension of 420 guilders. I'm staying with a very kind gentleman." ${ }^{17}$

In Prague, Majar lived modestly, mainly working on his books. He did not host anyone except the librarian from the Czech museum Jan Lego and gymnasium student Peter Nessia, who read newspapers and books to him. In Prague, Majar finished his book Saint Brothers Cyril and Methodius, which was published in 1884 by the Society of St. Mohor in Klagenfurt-Celovec. Judging by his letter to Kleinmayr dated 4 December 1884, Majar was interested in the situation at home, especially in the newspaper Slovenec (The Slovenian), which was published at that time by Russophile Ivan Hribar. But at the request of Kleinmayr to write something for the newspaper, Majar answered with a firm "no": "I do not write for any newspapers, I can't argue and behave obscenely as it is common now." 18

On 31 July 1892, Matija Majar died in Prague and was buried at the Olšany Cemetery. Majar's death resounded in Slovenia and Russia. The newspaper Slovan published an obituary written by Kleinmayr, Ljubljanski zvon published an article about Majar written by writer Karl Glaser. It said:

The heart of Matija Majar stopped beating; it was one of the most generous hearts that have ever beaten for the Slovenian nation. He worked selflessly all his life to make his dream come true; it was the creation of a united language for all Slavs, which would be based on their dialects. Glaser's conclusion was pessimistic: All his spiritual work and all the sacrifices exceeding his capabilities did not attract supporters to his ideal - Slavic unity. (Ljubljanski zvon, 1892: 564)

16 The State Archive of the Russian Federation, fund 1750, list 1, file 44.

17 Collection of manuscripts of the National and University Library, No. 39/40, Majar - Kleinmayr, December $6^{\text {th }} 1883$.

18 Collection of manuscripts of the National and University Library, No. 39/40, Majar - Kleinmayr, December $4^{\text {th }} 1884$. 


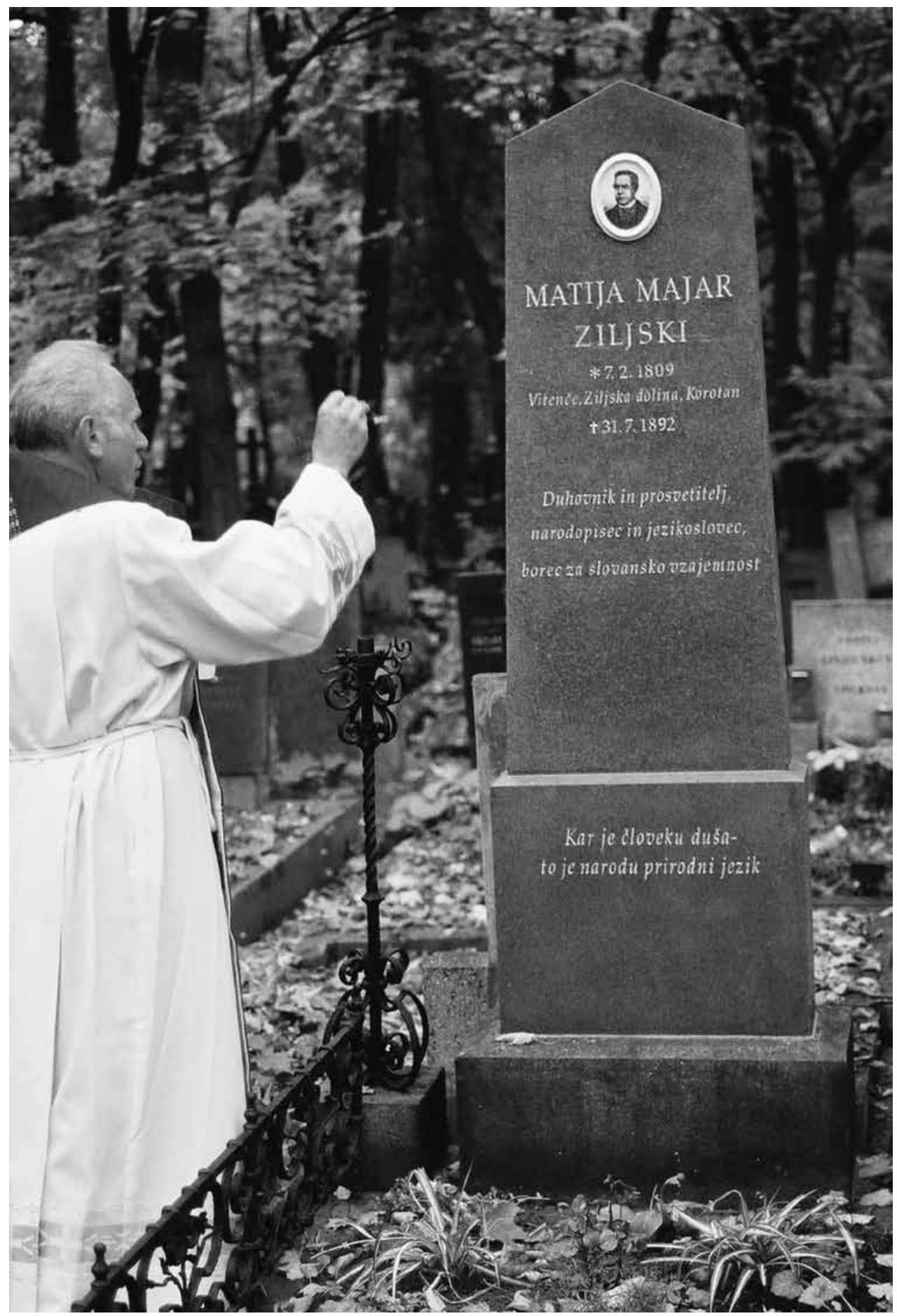

Stanko Trapp, priest of Gorje, sprinkling holy water over the grave of Matija Majar in Prague, at Olšany Cemetery (2002). 
In the Russian press, Majar's death was mentioned by the magazine Slavic Review. The obituary said: "He was one of the most enthusiastic followers of Kollar and an activist of Slavic rapprochement." 19

Undoubtedly, the creation of a Pan-Slavic language and advocacy of Slavic unity were uppermost in Majar's activity. However, Majar's main endeavor in the Slovenian national movement was his presentation of the program for a United Slovenia during the revolution in 1848-49. He was the first to raise this question in the press and he actively promoted this program both during the revolution and in the $1860 \mathrm{~s}$ and 1870 s.

Majar worked actively in public education, and he exerted a great effort to introduce a unified alphabet for Slovenians; he was one of the creators of Slovenian publishing houses (the Society of St. Mohor and Slovenska matica), and he struggled against the Germanization of schools in Slovenian regions. Finally, Majar's activities as an ethnographer should be also mentioned - he worked as a collector and a publisher of Slovenian folklore as well as a researcher of Slovenian folkways, customs, and clothes. It is hard to find among Slavic national activists a person like Matija Majar, who left a significant mark in various spheres of the cultural, educational and political life of his nation.

The work of Matija Majar was very important for the political and cultural development of the Slovenian people. At the first stage, Majar acted as a Pan-Slovenian activist; he collected folklore in all Slovenian regions, participated in the Illyrian movement, struggled for a unified alphabet for all Slovenians and for Slovenian schools. During the revolution in 1848-49, he was one of the main Slovenian ideologists and was the first to publish his political program United Slovenia. In addition, he proposed several variants of the Austrian-Slav program. After the revolution, Majar gradually turned away from Pan-Slovenian affairs. The main reason for this was his project to create a of a Pan-Slavic literary language. His position in this regard strengthened after his trip to the Ethnographic Exhibition in Moscow and his friendship with Russian Slavophiles. Majar dedicated not only his books, but also magazines Slovenska bčela and the Slavjan to this project. In Carinthia, Majar continued to participate in the Slovenian national movement (establishment of national societies including Trdnjava, atheneum, and the tabori movement) until his emigration to Prague.

\section{REFERENCES}

Čurkina, Iskra V.

1978 Slovenskoe nacional no-osvoboditel 'noe dviženie v XIX v. i Rossija. (Slovenian National-Liberation Movement in the $19^{\text {th }}$ Century and Russia.) Moskva: Nauka.

19 Slavic Review, Vol. III, St. Petersburg, September 1892, p. 154. 
Ilešič, Fran

1905 Korespondenca dr. Jos. Muršca. In: Zbornik Matice Slovenske. Vol. VII. Ljubljana: Narodna tiskarna, 47-49.

Kirilina, Liubov' A.

2000 Slovency i revoljucija 1848-1849 godov. (Slovenes and the Revolution 1848-1849.) Moskva: Institut slavjanovedenija RAN.

Pleterski, Janko

1965 Narodna in politična zavest na Koroškem: Narodna zavest in politična orientacija prebivalstva slovenske Koroške v letih 1848-1914. Ljubljana: Slovenska matica.

Prijatelj, Ivan

1955 Slovenska kulturnopolitična in slovstvena zgodovina. Vol. 1. Ljubljana: Državna založba Slovenije.

Zwitter Fran

1964 Slovenski politični prerod XIX st. v okviru evropske nacionalne problematike. Zgodovinski časopis 18: 75-153.

\section{MATIJA MAJAR - RAZSVETLJENEC, POLITIK, ZNANSTVENIK}

Matija Majar je znani slovenski razsvetljenec, politik, etnograf, novinar in filolog, ki je bil do 60. let 19. stoletja tesno povezan z narodnim prebuditeljstvom $v$ Sloveniji, pozneje pas panslovanskimi zamislimi. Do leta 1848 je sodeloval v javnih izobraževalnih prizadevanjih ter zbiral slovensko folklorno gradivo. Zavzemal se je za uvajanje poenotene abecede za vse Slovence in za ustanovitev slovenskih šol; menil pa je, da slovenski jezik nima svetle prihodnosti v izobraževanju in širjenju nacionalnih idej. Rešitev pred asimilacijo Slovencev pod Nemci in Italijani je po njegovem pomenil ilirizem, torej integracija Slovencev med druge Južne Slovane, s čimer bi nastal enoten narod skupnim knjižnim jezikom in kulturo. Leta 1848 je o tem objavil knjigo Pravila, kako izobraževati ilirsko narečje i u obče slavenski jezik.

$V$ revolucijskih letih 1848 in 1849 je Majar prvi predstavil politični program Zedinjena Slovenija in tudi program poenotenja vseh Slovanov v avstrijskih deželah, ki bi se v habsburški monarhiji povezali v administrativni enoti. Majar je promoviral svoje zamisli o časopisih Kmetijske in rokodelske novize in Slovenija in bil eden redkih slovenskih politikov, ki se mu je posrečilo zamisli predstaviti tudi kmetstvu. Analiza slovenskega tiska $v$ času revolucije kaže, da so Majarjeve zamisli pomembno vplivale tako na slovenske liberalce kot tudi neokonservativce.

Po uspešni protirevoluciji v Avstriji je oblast vnovič prevzelo plemstvo, Slovani pa so ostali brez privilegijev, za katere so se zavzemali. V zgodnjih 50. letih 19. stoletja se je Majar od panslovenstva preusmeril $k$ panslovanskim zamislim, ki jih je predstavil v časniku Slovenska bčla, leta 1865 pa je objavil delo Vzajemna slovnica ali mluvnica slavjanska, $v$ katerem je predstavil ideje o nastanku vseslovanskega knjižnega jezika.

$V$ 60. letih 19. stoletja so se pri njem oblikovala rusofilna stališca. Leta 1867 je objavil delo Slovnica ruska za Slovence, katere objavo je finančno podprl slovenski trgovec G. Blaž. 
Istega leta se je odzval na pobudo ruskih slavofilskih krogov in za Etnografsko razstavo $v$ Moskvi poslal dragoceno darilo - poročna oblačila s Koroške. Na to razstavo so ga povabili skupaj z desetimi slovenskimi nacionalnimi aktivisti, a le Majar se je prireditve dejansko udeležil, in to kljub nasprotovanju avstrijske vlade in verskih avtoritet. Izlet v Moskvo je še utrdil njegove rusofilske poglede, prijateljstva pa je sklenil tudi z ruskimi slavofili (npr. N. A. Popovom in M. P. Pogodinom). Od leta 1873 do 1875 je z njihovo finančno podporo izdajal časnik Slavjan, katerega osrednji namen je bila promocija zamisli o slovanski enotnosti in ustvarjanju panslovanskega literarnega jezika. Majar je verjel, da bi to moral biti umetno zasnovan jezik, ne pa da bi to vlogo prevzel kateri od slovanskih jezikov. V svojih prispevkih je trdil, da slovanska ljudstva ne bi smela opustiti svojih jezikov in navad, pred svetom pa bi morala nastopiti kot enoten narod z enovito kulturo.

Od poznih 60. let 19. stoletja so bile Majarjeve dejavnosti okrnjene na udeležbo v nacionalnem gibanju koroških Slovencev. Zaradi svojih pogledov so ga cerkveni dostojanstveniki prisilili, da je zapustil domače kraje in se izselil v Prago, kjer je umrl 31. julija 1892.

Dr. Iskra Vasiljevna Čurkina, The Institute of Slavonic Studies of the Russian Academy of Sciences, 119334 Moscow, Leninsky Prospect, build. 32-A 